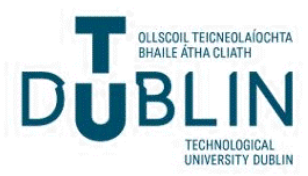

Technological University Dublin ARROW@TU Dublin

2016-4

\section{Using Contribution Analysis to evaluate small \& medium enterprise support policy}

Anthony Paul Buckley

Technological University Dublin, anthony.buckley@tudublin.ie

Follow this and additional works at: https://arrow.tudublin.ie/buschmaroth

Part of the Business Commons

\section{Recommended Citation}

Buckley, Anthony Paul, "Using Contribution Analysis to evaluate small \& medium enterprise support policy" (2016). Other. 17.

https://arrow.tudublin.ie/buschmaroth/17

This Other is brought to you for free and open access by the School of Marketing at ARROW@TU Dublin. It has been accepted for inclusion in Other by an authorized administrator of ARROW@TU Dublin. For more information, please contact arrow.admin@tudublin.ie, aisling.coyne@tudublin.ie, gerard.connolly@tudublin.ie.

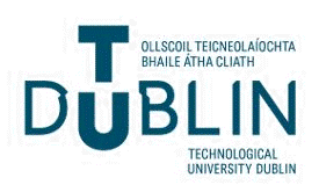




\title{
Using Contribution Analysis to evaluate small \& medium enterprise support policy
}

\author{
Anthony P. Buckley
}

\begin{abstract}
This research illustrates a pragmatic approach to evaluating the small and medium sized enterprise policy support in small or intermediate $N$ research situations. A public interest perspective is taken. The suggested approach is most appropriate in settings where, for a variety of reasons, a study is unable to meet the requirements of a true experimental design (e.g. random assignment, establishment of counterfactuals, control groups, random samples, etc.). This approach will deliver findings on the contribution of the multiple factors influencing a result and will show whether the implicit theory of change for the policy under evaluation makes the expected contribution to the observed result and in what way. The Contribution Analysis finds that the theory of change for the policy under analysis was not verified in the study period. The outputs and outcomes of the analysis broadly support this conclusion. Moreover, the study finds that the primary limiting factor on profitable small and medium sized enterprise growth was the 'limited endowments of managerial resources' (Penrose, 1959) to manage the value-adding growth process and the lack of 'well thought out, well managed projects' (Walsh, 1985) and not lack of access to equity finance as surmised by policymakers. Whilst Ireland is used as the case example in the study, there are significant lessons for policy evaluators in other late-developing states and in regions with policy autonomy in the enterprise domain.
\end{abstract}

Keywords Contribution Analysis, evaluation, $\underline{\text { firm growth, }} \underline{\text { SME policy support }}$ 